\title{
突発性難聴に対するアシクロビルの使用経験
}

\author{
山口 宗一・鴫原俊太郎・池田稔
}

\section{A Clinical Study of Acyclovir Therapy for Sudden Sensorineural Hearing Loss}

\author{
Soichi Yamaguchi, Shuntaro Shigihara and Minoru Ikeda \\ (Nihon University School of Medicine)
}

\begin{abstract}
The etiology of sudden sensorineural hearing loss is unknown, but viral infection is suspected as one possible cause. We retrospectively studied 102 sudden sensorineural hearing loss patients to evaluate the efficacy of acyclovir therapy. Acyclovir had been administered to 25 patients as single therapy or in combination with corticosteroid or batroxobin. They were given $750 \mathrm{mg}$ of acyclovir per day intravenously. These patients were compared with the other 77 patients treated without acyclovir. Hearing recovery was assessed by the criteria of the Sudden Deafness Research Group of the Japanese Ministry of Health and Welfare. In the patients treated with acyclovir, the rate of complete recovery was $56.0 \%$, the rate of recovery was $80.0 \%$, and the rate of efficiency was $88.0 \%$. We found significantly better recovery in the group therapy by acyclovir than in the group without acyclovir.
\end{abstract}

Key words : acyclovir, therapy, sudden deafness

はじめに

突発性難聴は原因不明の急性感音難聴である．現在ま でその原因について種々の検討が行われてきたが，依然 として結論はでていない，循環障害，内耳空破裂，代謝 障害, 自己免度等が突発性難聴の原因として指摘されて いる1）が，ウイルス性内耳炎む原因として有力なものの 一つである．突発性難聴はその原因が不明であることか ら治療法にもステロイド風投与, 循環改善片投与, 高圧 酸素療法などさまざまなものがみられる，突発性難聴の 原因にウイルス感染が関与しているという考えに基づい た治療法としてはインターフェロンを使用した報告がみ られる233. .また最近は抗ウイルス剤であるバラシクロビ ルの内服治療に関する検討報告がみられている4).

今回われわれは過去 5 年間に当科で入院加療した中等 度以上の突発性難聴 102 例のうち 25 例に対して単純へル ペスウイルス（HSV）および水痘・帯状疮疹ウイルス (VZV) の治療薬であるアシクロビルを使用した. その治
療効果についてレトロスペクテイブに検討したところ， アシクロビルの使用群においてより良好な治療効果が認 められたので若干の考察を加えて報告する.

\section{対象}

平成 9 年 1 月から平成 13 年 12 月の 5 年間に当科で入 院加療した中等度以上の突発性難聴症例は102例であり, これらを検討対象とした. アシクロビルを使用した症例 は 25 例 $(24.5 \%)$ で, 非使用例は 77 例 (75.5\%) であっ た. アシクロビルの投与は平成 9 年 $1 \sim 4$ 月と $9 \sim 10$ 月, 平成 10 年 $7 \sim 12$ 月, 平成 11 年 $2 \sim 5$ 月の計 16 力 月間に入院した突発性難聴 25 例すべてに行われた。 ま た，この $4 つ の$ 期間は無作為に選定した. したがって, アシクロビルを投与するための特別な条件は何ら設定し なかった。

アシクロビル使用例 25 例は, 男性 10 例, 女性 15 例, 年齢は $19 \sim 66$ 歳（平均 $46.7 \pm 13.8$ 歳）であり, 受診ま 


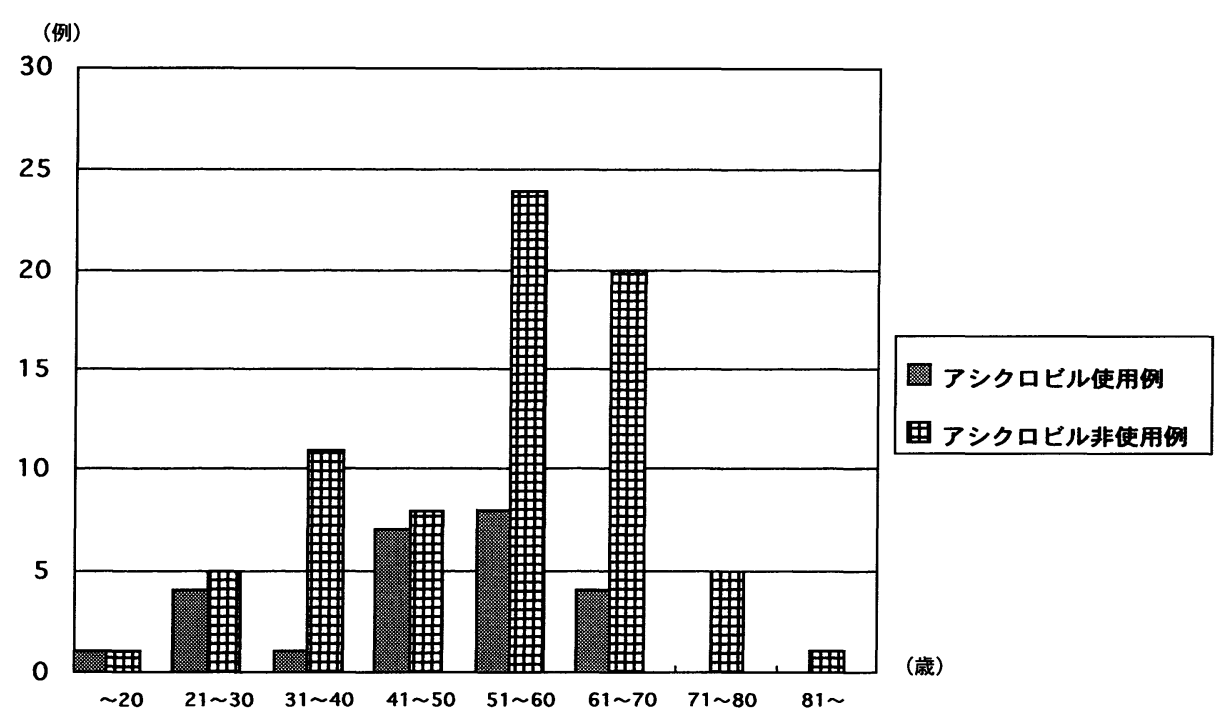

図 1 アシクロビル使用群と非使用群の年代別分布

表 1 初診時の聴力障害程度の比較

\begin{tabular}{l|c|c}
\hline \hline & アシクロビル使用例 (25 例) & アシクロビル非使用例 $(77$ 例 $)$ \\
\hline \multicolumn{1}{c|}{ 初診時平均聴力 } & $82.6 \pm 16.3 \mathrm{~dB}$ & $85.9 \pm 17.3 \mathrm{~dB}$ \\
\hline grade $2(40 \mathrm{~dB}$ 以上 $60 \mathrm{~dB}$ 未満 $)$ & $1(4 \%)$ & $5(6.5 \%)$ \\
grade $3(60 \mathrm{~dB}$ 以上 $90 \mathrm{~dB}$ 未満) & $18(72 \%) * 1$ & $40(51.9 \%) * 1$ \\
grade $4(90 \mathrm{~dB}$ 以上) & $6(24 \%) * 2$ & $32(41.6 \%) * 2$
\end{tabular}

$*^{1} \mathrm{p}=0.13$

$*^{2} \mathrm{p}=0.11$

での日数は発症から $1 \sim 8$ 日（平均は $3.0 \pm 2.5$ 日）で あった. 入院日数は $13.8 \pm 5.3$ 日, めまいの随伴は 3 例 （12\%）で認められた。

一方, アシクロビル非使用例 77 例は, 男性 42 例, 女 性 35 例，年齢は $14 \sim 82$ 歳（平均 $53.2 \pm 14.4$ 歳）であ り, 受診までの日数は発症から $1 \sim 10$ 日（平均は $3.8 \pm$ 4.7 日）であった。 入院日数は $14.1 \pm 5.2$ 日，めまいの 随伴は 18 例（23.4\%）で認められた。

対象症例の年齢分布を図 1 亿示した. 全体では 20 歳以 下あるいは 70 歳以上の症例数は少なく, 50 歳代と 60 歳 代で過半数を占めた. アシクロビル使用例は非使用例に 比べて平均年齢はやや若いが，スチューデントの $\mathrm{t}$ 検定 で統計学的に有意差は認めなかった $(\mathrm{p}=0.97)$.

アシクロビル使用例とアシクロビル非使用例の初診時 聴力を比較した（表 1). 5 分法による平均聴力はそれぞ れ $82.6 \pm 16.3 \mathrm{~dB}, 85.9 \pm 17.3 \mathrm{~dB}$ でスチューデントの $\mathrm{t}$
検定で統計学的に有意差は認めなかった（ $\mathrm{p}=0.86 ）$ 。 ま た聴力障害程度を grade 別に検討したが, grade 3 では $\mathrm{p}$ $=0.13$, grade 4 では $\mathrm{p}=0.11$ とともに $\chi^{2}$ 検定でアシク ロビル使用例，アシクロビル非使用例との間で有意差は 認めなかった。

\section{方法}

アシクロビルは 1 日 3 回, 1 回 $250 \mathrm{mg}$ を 8 時間おきに 点滴静注し, 計 1 日 $750 \mathrm{mg}$ を 7 日間使用した. アシク ロビル単独投与が 5 例, アシクロビルに他剤を併用した 例はステロイド併用例が 10 例, バトロキソビン併用例が 2 例，ステロイドとバトロキソビン併用例が 8 例であっ た。一方，アシクロビル非使用例はステロイド単剤投与 が 15 例, ステロイドとバトロキソビンの併用例が 52 例, ステロイドとインターフェロンの併用例が 5 例, ステロ イドとバトロキソビン，インターフェロンの 3 鼡併用例 
表 2 突発性難聴聴力回復の判定基準

\begin{tabular}{c|l}
\hline \hline 治 癒 & $\begin{array}{l}\text { 1) } 250,500,1000,2000,4000 \mathrm{~Hz} \text { の聴力レベ } \\
\text { ルが } 20 \mathrm{~dB} \text { 以内に戻ったもの } \\
\text { 2) 健側聴力が安定と考えられれば, 患側がそ } \\
\text { れと同程度をて改善した時 }\end{array}$ \\
\hline 著明回復 & $\begin{array}{l}\text { 上記 } 5 \text { 周波数の算術平均値が } 30 \mathrm{~dB} \text { 以上改善し } \\
\text { たとき }\end{array}$ \\
\hline 回 復 & $\begin{array}{l}\text { 上記 } 5 \text { 周波数の算術平均値が } 10 \sim 30 \mathrm{~dB} \text { 未満改 } \\
\text { 善したとき }\end{array}$ \\
\hline 不 変 & 上記 5 周波数の算術平均值が $10 \mathrm{~dB}$ 未満の変化
\end{tabular}

が 1 例, インターフェロン単独投与が 2 例, インターフェ ロンとバトロキソビンの併用例が 2 例であった.

ステロイドはコハク酸メチルプレドニゾロンナトリウ ムを $250 \mathrm{mg}$ より漸減しながら約 7 日間使用し，バトロ キソビンは血中フィブリノーゲン值を 80 〜 100 に保つよ うにして入院期間中使用した. 聴力固定までは原則とし てビタミン $\mathrm{B}_{12}$ 製剤, 脳代謝改善剤の ATP 製剤, 末梢循 環改善剤のカリジノゲナーゼを処方した.

厚生省急性高度難聴調查研究班の重症度分類5) に従っ て対象症例の聴力障害を grade $2 \sim 4$ に分類し, 聴力改 善の判定基準（表 2）に従い，固定時聴力を治癒，著明回 復, 回復, 不変の 4 つに分類した.

また（初診時聴力ー判定時聴力）/初診時聴力ー健側 聴力） $\times 100 \%$ で求めた聴力改善率 6) についても検討し た. また著明回復以上を治療効果ありとして $\chi^{2}$ 検定を 行った.

\section{結果}

1.アシクロビル使用群の治療結果（表 3）

アシクロビルを使用した 25 症例全体における治癒は 14 例で治癒率 $56.0 \%$, 治癒に著明回復を加えた改善例は 20 例で改善率 $80.0 \%$, 回復まで加えた有効例は 22 例で 有効率 $88.0 \%$ であった. grade 4 の有効例 6 例には, 眩
量を伴った 3 例を含むスケールアウト症例が 4 例あった が, 結果的に不変例はなく 5 例が著明回復以上で, 1 例 が回復と有効率 100\%であり良好な結果であった。 また 聴力改善率は $76.8 \%$ であった。

2. アシクロビル非使用群の治療結果（表 3）

アシクロビルを使用しなかった77症例全体での治癒は 19 例で治癒率 $24.7 \%$, 治癒に著明回復を加えた改善例は 43 例で改善率 $55.8 \%$, 回復まで加えた有効例は 64 例で 有効率 $83.1 \%$ であった. grade 4 では治癒が 4 例で治瘉 率 $12.5 \%$ と低いものの, 改善例は 32 例中 18 例で改善率 56. 3\%であった。 また聴力改善率は $54.2 \%$ あっった。

3. 両群の治療結果の比較（表 3）

アシクロビル使用例の改善率 $80.0 \%$ は, アシクロビル 非使用例の改善率 $55.8 \%$ と比較してフィッシャーの直接 確率法において統計学的に有意差を認めた（p<0.05）. またアシクロビル使用群の聴力改善率 $76.8 \%$ は,アシク ロビル非使用群の $54.2 \%$ に対し, 統計学的に有意に良好 であった（p<0.01）.

重症例である grade 4 について両群を比較した. 初診 時平均聴力はアシクロビル使用例が $107.7 \pm 6.4 \mathrm{~dB}$, 非 使用例が $104.0 \pm 7.0 \mathrm{~dB}$ であり，スチューデントの $\mathrm{t}$ 検 定において両群に統計学的有意差は認めなかった（p= 0.25).アシクロビル使用例では治癒が 6 例中 1 例で治癒 率 $16.7 \%$ で, 改善例は 6 例中 5 例で改善率 $83.3 \%$ であっ た.アシクロビル非使用例では治癒率が $12.5 \%$ で改善率 は $56.3 \%$ であり，アシクロビル使用例がより良好では あったが, 統計学的に有意差は認めなかった $(\mathrm{p}=0.22)$. また聴力改善率はアシクロビル使用例が $48.9 \%$, 非使用 例が50.5\%で両群に統計学的に有意差は認めなかった (p $=0.91$ ).

また grade 3 については, アシクロビル使用例の初診 時平均聴力が $76.1 \pm 6.4 \mathrm{~dB}$, 非使用例は $76.8 \pm 7.3 \mathrm{~dB}$ であり，両者に有意差は認められなかった。 また，アシ

表 3 聴力障害程度と治療成績

\begin{tabular}{c|c|c|c|c|c|c|c|c}
\hline \hline 聴力障害程度 & \multicolumn{2}{|c|}{ 治癒 } & \multicolumn{2}{|c|}{ 著明回復 } & \multicolumn{3}{|c|}{ 回復 } & \multicolumn{3}{c}{ 不変 } \\
\hline アシクロビル & 使用 & 非使用 & 使用 & 非使用 & 使用 & 非使用 & 使用 & 非使用 \\
\hline grade 2 (6 例) & 0 & 0 & 0 & 2 & 1 & 1 & 0 & 2 \\
grade 3 (58 例) & 13 & 15 & 2 & 8 & 0 & 10 & 3 & 7 \\
grade 4 (38 例) & 1 & 4 & 4 & 14 & 1 & 10 & 0 & 4 \\
\hline 全体 (102 例) & 14 & 19 & 6 & 24 & 2 & 21 & 3 & 13
\end{tabular}


クロビル使用例の治瘉が 18 例中 13 例で治癒率 $72.2 \%$, 改善例が 18 例中 15 例で改善率 $83.3 \%$ であり, アシクロ ビル非使用例では治疻が 40 例中 15 例で治癒率 $37.5 \%$, 改善例が 18 例中 13 例で改善率 $57.5 \%$ であった. 改善率 および治瘉率ともにアシクロビル使用例がフィッシャー の直接確率法において有意に良好であった（ $\mathrm{p}<0.05 ）$. また聴力改善率はアシクロビル使用例が $95.8 \%$, 非使用 例が $68.1 \%$ で両群に統計学的に有意差を認めた（p< 0. 01).

4. アシクロビル使用例の年齢別治療結果（表 4)

聴力の不変であった症例は $20,40,50$ 歳代に 1 例ずつ 認めた。 いずれも聴力障害程度は grade 3 で眩量症例で はなく，発症から初診までの日数はそれぞれ 4 日，5 日， 8 日であった. 50 および 60 歳代の治癒率はともに 50.0 \%, 改善率はそれぞれ 87.5\%，100\%であった．高跲者 の治療成績が悪いという傾向はなく，明らかな年龄によ る差は認めなかった。

5. ウイルス抗体価について

アシクロビルを投与した 25 例中 23 例に対し, 初診時 に CF 法による HSV と VZV に対する抗体価，むしくは ELISA法による抗HSVIgG抗体と抗VZVIgG抗体を検查し た. HSV に対する CF 法で 32 倍以上，もしくは抗 HSVIgG 抗体価が 200 以上と比較的高い抗体価を有していた症例 は 1 例でその抗 HSVIgG 抗体価は 220 であった。この症 例は第 2 病日に受診し, 治療の結果治瘉に至っている. またVZVに対するCF法で 32 倍以上，もしくは抗VZVIgG 抗体価が 200 以上と比較的高い抗体価を有していた症例 は 1 例でその抗 VZVIgG 抗体值が 222.4 であった。 この 症例は第 3 病日に受診し, 治療の結果著明回復に至って いる．上記症例と合わせ 2 例 $100 \%$ が著明回復以上の治
療効果であった。

一方, アシクロビル非投与群 77 例中, 抗体価測定が行 われたのは 21 例で，そのうち前記の条件で抗 HSV およ び抗 VZV 抗体価が上昇していたのは 7 例であった。 その 聴力予後は著明回復が 4 例 (57.1\%), 回復が 1 例, 不変 が 2 例であり,また聴力改善率の平均は $38.5 \%$ であった.

6. ステロイド使用例，非使用例の比較

ステロイドを使用した症例は 91 例であり, 平均年踰は 52.0 歳で, 非使用症例の 49.1 歳と比べ有意差を認めな かった $(\mathrm{p}=0.53)$. 受診までの日数の平均は 3.60 日で あり,これは非使用症例の 3.64 日と比べて有意差を認め なかった $(p=0.98)$. ステロイド使用例と非使用例の初 診時の 5 分法平均聴力はそれぞれ $85.5 \mathrm{~dB}$ と $89.2 \mathrm{~dB}$ で 統計学的には有意差は認めていない（ $\mathrm{p}=0.49 ）$.

ステロイド使用群の治療結果は, 使用した症例全体に おける治癒率は $30.8 \%$ であり, 治癒に著明回復を加えた 改善率は $60.4 \%$ であった。一方, 非使用症例全体におお る治癒率は $45.6 \%$, 改善率は $72.7 \%$ であり, 両者間の治 療効果に有意差は認めなかった $(p=0.33)$.

さらにアシクロビルを使用した 25 例を, ステロイドを 併用した 18 例と使用しなかった 7 例とに分けて検討し た. 平均年齢はステロイド併用例が 46.0 歳で, 非併用例 の 48. 6 歳と比較して有意差は認めなかった $(p=0.68)$. 初診までの日数はステロイド併用例が 2.5 日に対し, 非 併用例は 4.4 日と有意差を認めた $(\mathrm{p}<0.05)$. 初診時聴 力は併用例が $82.7 \mathrm{~dB}$ に対し, 非併用例が $82.3 \mathrm{~dB}$ と有 意差は認めなかった $(\mathrm{p}=0.96)$.

アシクロビルを使用した群で，ステロイドを併用した 改善率は $77.8 \%$ であった。一方, アシクロビルを使用し たが，ステロイドを併用しなかった例における改善率は

表 4 年齢別にみた治療効果

\begin{tabular}{|c|c|c|c|c|c|c|c|c|}
\hline \multirow{2}{*}{$\begin{array}{c}\text { 年代 } \\
\text { アシクロビル }\end{array}$} & \multicolumn{2}{|c|}{ 治癒 } & \multicolumn{2}{|c|}{ 著明回復 } & \multicolumn{2}{|c|}{ 回復 } & \multicolumn{2}{|c|}{ 不変 } \\
\hline & 使用 & 非使用 & 使用 & 非使用 & 使用 & 非使用 & 使用 & 非使用 \\
\hline ～20（2 例） & 1 & 1 & 0 & 0 & 0 & 0 & 0 & 0 \\
\hline$\sim 30$ (10 例) & 2 & 1 & 0 & 3 & 1 & 2 & 1 & 0 \\
\hline$\sim 40$ (11 例) & 1 & 2 & 0 & 3 & 0 & 3 & 0 & 2 \\
\hline$\sim 50$ (14 例) & 4 & 1 & 1 & 2 & 1 & 3 & 1 & 1 \\
\hline$\sim 60$ (34 例) & 4 & 7 & 3 & 8 & 0 & 5 & 1 & 6 \\
\hline$\sim 70$ (25 例) & 2 & 6 & 2 & 7 & 0 & 5 & 0 & 3 \\
\hline$\sim 80$ (5 例) & 0 & 1 & 0 & 2 & 0 & 1 & 0 & 1 \\
\hline$\sim 90$ (1 例) & 0 & 0 & 0 & 0 & 0 & 1 & 0 & 0 \\
\hline
\end{tabular}


85. 7\%であり，両者間の治療効果に有意差は認めなかっ た $(\mathrm{p}=0.91)$.

7. バトロキソビン使用例, 非使用例の比較

バトロキソビンの使用方法は原則として血中フィブリ ノーグン值を $80 \sim 100$ に保つように随時検查しながら， $5 \sim 10$ 単位を約 1 時間加けて点滴静注し, 聴力検査で改 善傾向がなくなった時を終了の目安とした。 また，バ卜 ロキソビン使用の判断は主治医に任された。

使用した症例は 65 例であり, 平均年齢は 51.7 歳で, 非使用症例の 51.5 歳と比べ有意差を認めなかった（ $\mathrm{P}=$ 0.93). 受診までの平均日数は 3.8 日であり,これも非使 用例の 3.2 日と比較して有意差を認めなかった（P= 0.45). バトロキソビン使用例と非使用例の初診時の 5 分 法平均聴力はそれぞれ $86.6 \mathrm{~dB}$ と $84.6 \mathrm{~dB}$ で統計学的に は有意差は認めていない（ $\mathrm{p}=0.58 ）$.

バトロキソビン使用群の治療結果は, 使用した症例全 体における治癒率は $24.6 \%$, 改善率は $55.4 \%$ であった。 これらは非使用群の治癒率 $45.9 \%$, 改善率 $73.0 \%$ と比較 して治療効果は劣っていた $(\mathrm{p}<0.01)$.

\section{考察}

突発性難聴の病因として循環障害や内耳空破裂, 代謝 障害, 自己免疫そしてウイルス感染などが挙げられ検討 されているが，現在までその病因に関する統一された見 解は得られていない. したがって現在のところ病因論に 裏付けられた有効な治療法む確立されていない.

これまで突発性難聴の治療にはさまざまな薬剤に加 え, 高圧酸素療法や星状神経節ブロック等が用いられて きた. 薬剤として最も一般的には抗炎症作用や抗浮腫作 用等を有する副腎皮質ステロイドホルモン剤が使用さ れ，ステロイドホルモンが唯一の有効な治療薬であると するものもある7). その他末梢循環改善を目的にプロス タグランデイン $\mathrm{E} 1$ やバトロキソビン，抗ウイルス作用 を目的にインターフェロン等が用いられてきた.しかし， これらの薬剤に関する報告は治療成績にばらつきがあ り，特に症例数の少ない報告にその傾向が高く，全体と しては有効な治療法はないのではないかとも報告されて いる ${ }^{8)}$. また抗ウイルス剤であるバラシクロビルの内服 治療による検討も行われているが，突発性難聴に対する 効果は, 対照として行われた副腎皮質ステロイド単独治 療の場合と有意差をみていない ${ }^{4}$. 本報告では突発性難 聴のウイルス原因説に基づき，HSV および VZV に有効
な抗ウイルス剤であるアシクロビルを点滴静注で用いて 突発性難聴に対する有効性を検討した。 先に引用した Tucci ら ${ }^{4)}$ の検討で用いたバラシクロビルはアシクロビル のプロドラッグである. したがってアシクロビルの効果 をみる点では，最終的に同じということになるが，われ われの薬剤投与は血管内であり, 内服に比べ血中濃度の 十分な上昇が期待できる.

突発性難聴は内耳障害に関する病理組織学的所見がウ イルス性内耳炎のものと酷似していることから，原因と してウイルス感染の関与の可能性が指摘されている9 ${ }^{9}$. 関 与するウイルスについてはヘルペスウイルスや麻疹ウイ ルス，サイトメガロウイルス，風疹ウイルス等さまざま なものが推察されているが，いずれも突発性難聴との明 らかな因果関係は解明されていないのが現状である.

ところで HSV がヒトの顔面神経膝神経節や, 内耳神経 のGasserの神経節やらせん神経節などに潜伏感染してい ることはすでに報告されている ${ }^{10)}$ 。ベル麻瘏はこのうち の膝神経節に潜伏した HSV が再活性化し, 顔面神経障害 をきたしたものといわれている11)。この考えを背景に， ベル麻痺の治療に際しステロイド剤にアシクロビルを併 用することで良好な結果が得られたと報告されてい る ${ }^{1213)}$. このような背景を考えた場合, 同じようにへル ペスウイルスの関与が疑われる突発性難聴に対しアシク ロビルの治療効果を検討してみることは興味深いところ である14)15).

本疾患の自然治癒率については $65 \%{ }^{7)}$ と比較的良好な 報告むあるが, 朝隈ら ${ }^{8)}$ は過去 10 年間に報告された突発 性難聴の治瘉率の平均は $30.8 \%$ であると述べている. わ れわれの今回の検討ではアシクロビル使用群は治瘉率56 $\%$, 改善率 $80 \%$ であり, これまでの本邦における突発性 難聴報告例8) と比較して良好な成績であった。 また，わ れわれの今回の検討ではアシクロビル非使用群と比較し てアシクロビル使用群の改善率は, フィッシャーの直接 確率法で有意に良好であった $(\mathrm{p}<0.05)$ ．さらにアシク ロビルを使用した25例をステロイド併用例と非併用例に 分けて検討した結果，両群の治療結果に統計学的有意差 は認めなかったことからもアシクロビルの有効性が示唆 された。

聴力障害程度が grade 3 の症例ではアシクロビル使用 例の改善率 $83.3 \%$ は非使用例の $57.5 \%$ に比べ有意に良好 であった（ $<<0.05 ）$. 治瘉率もアシクロビル使用例が $72.2 \%$ ，非使用例が $37.5 \%$ で統計学的に有意差を認めた 
$(\mathrm{p}<0.05)$. 次いで聴力障害が高度な grade 4 の症例に 限ってアシクロビルの有効性を検討すると, アシクロビ ル使用例の改善率 $83.3 \%$ は非使用例の改善率 $56.3 \%$ に比 べ良好であった。 しかし, 症例数が十分ではないためか 両者に統計学的有意差は認められず, 今後症例数を増や して検討する必要があるものと思われた。

アシクロビルが投与された 25 例中 23 例では初診時に HSVもしくはVZV抗体価の検索がCF法もしくはELISA法 にて行われた. 抗体価が CF 法で 32 倍以上, または ELISA 法で IgG が 200 以上の条件を満たした症例は 2 例存在し た. それらは 1 例が著明改善, 1 例が治疻に至っている. 一方, アシクロビルを投与しなかった症例では 77 例中 7 例で同様の抗体価上昇が認められたが，そのうち 2 例が 聴力不変であった，そして改善率は $57.1 \%$, 有効率は 71. 4\%であった。 この結果は, 症例数が少ないものの, アシクロビル投与群の抗体価の上昇を示した症例の改善 率 $100 \%$ に比較して不良であった. アシクロビル投与群 にみられた以上のような有効な治療効果は，突発性難聴 もべル麻痺と同様に, 少なくとも一部に HSV が関与して いる可能性があることを示唆しているものと思われる. この点については今後も検討される必要があるものと思 われる。

またバトロキソビンについても検討したが，使用例の 治療効果が統計学的に有意に劣っていた。これは前述し たようにバトロキソビンの投与に関しては主治医に任さ れており,投与開始時期む入院当日から 10 日前後と統一 されていなかった．そのため，ステロイド投与で十分な 効果が得られなかったために, バトロキソビンが追加し て使用されたと思われる症例も含まれており，治療成績 が劣っていた原因の一つと考えられる. しかし，ステロ イド投与で無効だった症例に対するバトロキソビンの有 効性む報告されており ${ }^{16)}$ ，今後症例を重ねて検討する必 要があると思われる.

今回のわれわれの臨床検討はレトロスペクテイブに行 われたものであり，プラセボコントロールを設定したプ ロスペクテイブな二重盲験による撖密な検討ではない。 理想的には無治療の群をランダムに設定してアシクロビ ルの有効性を検討することが望ましいわけであるが，現 実的には突発性難聴例において無治療群を設定すること は容易ではない，今回のわれわれの検討はそのような背 景のなかで, 突発性難聴で最も一般的に使用されるステ ロイド剤に加え, 抗血栓性末梢循環改善薬であるバトロ
キソビンの併用例を用いて，抗ウイルス薬であるアシク ロビルの有用性について検討を加えたものである。 また 今回のスタデイは, $5 \%$ 有意基準において年齢, 初診時聴 力, 発症から受診までの日数, 眩量の有無についてアシ クロビル使用例と非使用例に有意差がなかったものの， すべての項目でアシクロビル使用例は予後がよいとされ る方向に傾いており，ランダムに使用したが，結果的に もともと治りが良い群に使用された可能性はある。しか 乙突発性難聴の有効な治療法が確立されていない現状に おいて，抗ウイルス治療薬の有効性について検討してみ ることは今後の本疾患に対する治療法を考えていくため に少なからず意義のあることと思われる．われわれは今 回の点滴静注によるアシクロビル投与で得られた比較的 良好な治療成績を踏をえて，今後プロスペクテイブに本 治療法の有効性を検討する価值があるものと考える.

\section{まとめ}

われわれは中等度以上の聴力障害により入院加療を 行った突発性難聴症例 102 例についてアシクロビル使用 例と非使用例に分け，アシクロビルの点滴治療の有効性 についてレトロスペクテイブな検討を行った. アシクロ ビル使用例は非使用例に比べ統計学的に有意に良好な聴 力改善を示した．突発性難聴に対するアシクロビルの点 滴治療の有効性が推察され，今後プロスペクテイブなよ り詳細な検討を行う価值があるものと思われた。

本稿は平成 13 年 5 月, 第 103 回日本耳鼻咽喉科学会（東京 都）にて発表した。

\section{参考文献}

1）神崎 仁，佐藤美奈子：突発性難聴. CLIENT 21. 6 聴覚. $336 \sim 345$ 頁, 中山書店, 東京, 2000.

2）高橋春雄, 内藤 泰, 野々村光栄, 他 : 突発性難聴のイン ターフェロン少量療法. 耳鼻臨床 $88: 711 \sim 714,1995$.

3）金丸眞一, 福島英行, 中村 一, 他 : インターフェロンに よる突発性難聴の治療. 耳鼻臨床 $88: 1123 \sim 1127,1995$.

4) Tucci DL, Farmer JC Jr., Kitch RD, et al. : Treatment of sudden sensorineural hearing loss with systemic steroids and valacyclovir. Otol Neurotol $23: 301 \sim 308,2002$.

5）柳田則之：突発性難聴に対するステロイド治療の検討．厚 生省特定疾患 急性高度難聴調查研究班. 昭和 59 年度研究 業績報告書 : 79 頁, 1985 .

6）秦地秀信, 神崎 仁: 突発性難聴の予後の回帰分析. 日耳 鼻 $91: 1203 \sim 1030,1988$. 
7) Eisenman D and Arts HA : Effectiveness of treatment for sudden sensorineural hearing loss. Arch Otolaryngol Head Neck Surg $126: 1161 \sim 1164,2000$.

8）朝隈真一郎, 志多 亨: 本邦に抒ける過去 10 年間に報告さ れた突発性難聴の治療成績の変遷. 日耳鼻 104: $489 \sim 494$, 2001.

9) Khetarpal U, Nadol JB and Glynn RJ : Idiopathic sudden sensorineural hearing loss and postnatural labyrinthitis; a statistical comparison of temporal bone findings. Ann Otol Rhinol Laryngol $99: 969 \sim 976,1990$.

10) Takasu T, Furuta $Y$, Sato KC, et al. : Detection of latent herpes simplex virus DNA and RNA in human geniculate ganiglia by the polymerace chain reaction. Acta Otolaryngol (Stockh) $122: 1004 \sim 1011,1992$.

11) Murakami S, Mizobuchi M, Nakashiro $Y$, et al. : Bell palsy and herpes simplex virus; idenfication of viral DNA in endoneurial fluid and muscle. Ann Intern Med $124: 27 \sim 30,1996$.

12) 羽藤直人, 本田伸光, 暁 清文, 他 : ベル麻痺に対するア シクロビループレドニン併用内服療法. 日耳鼻 103:133〜
138,2000

13) Adour KK, Ruboyianes JM, Von Doersten PG, et al. : Bell's palsy treatment acyclovir and prednisone compared with prednisone alone; a double-blind, randomized, controlled trial. Ann Otol Rhinol Laryngol $105: 371 \sim 378,1996$.

14) Hughes GB, Freedman MA, Haberkamp TJ, et al. : Sudden sensorineural hearing loss. Otolaryngol Clinic North Am 29 : $393 \sim 405,1996$.

15) Tucci DL : Sudden sensorineural hearing loss; a viral etiology? Arch Otolaryngol Head Neck Surg 126: $1164 \sim 1165,2000$.

16）弘重光一, 山田洋一郎, 田中正美, 他 : 突発性難聴に対す るバトロキソビン製剤の効果. 耳鼻臨床 補 $78: 83 \sim 88$, 1995. 